\title{
So You Want To Work In A Museum... Guiding the Careers of Future Museum Information Professionals
}

Paul F. Marty

College of Information

Florida State University

marty@ci.fsu.edu

\begin{abstract}
This paper presents results from twenty-one semi-structured interviews with museum information professionals who were asked about their experiences working with information resources, tools, and technologies in the museum environment. These interviews were analyzed to determine common elements in the participants' career paths, educational backgrounds, and on-the-job experiences. Based on this analysis, we identified five factors that we believe will influence the ability of Library and Information Science (LIS) students to succeed as information professionals in museums. This paper will provide guidance for LIS students who wish to pursue museum careers, answering the question, "How do I become an information professional in a museum?"
\end{abstract}

\section{Keywords}

Museum information professionals; library and information science education; museum studies; museum informatics; museum careers.

\section{Notice}

This is the author's version of a work that was accepted for publication in the Journal of Education for Library and Information Science. Changes resulting from the publishing process, such as peer review, editing, corrections, structural formatting, and other quality control mechanisms may not be reflected in this document. Changes may have been made to this work since it was submitted for publication. A definitive version was subsequently published in the Journal of Education for Library and Information Science, 46 (2), 115-133. 


\section{Introduction}

As museum professionals and visitors become more information-savvy, and their information needs and expectations become more complex, the role of information professionals working in museums worldwide has increased dramatically in importance. ${ }^{1}$ The international scope of this trend can easily be seen in the growing number of conferences, journals, and publications around the world focusing on "museum informatics."

Many individuals, from current museum professionals to students planning museum careers, are interested in how advances in information science will affect museums. Museum employees who wish to better understand the role of the museum in the information society study how Library and Information Science (LIS) applies both to them and their museums. LIS students who wish to contribute their skills to museums ask, "How do I become an information professional in a museum?"

This is a very interesting, yet incredibly difficult question to answer. Everyone seems to have some sort of intuitive understanding of what an information professional in a museum does, and for years researchers have proposed the need for more museum information professionals. ${ }^{3}$ On the other hand, exactly what an information professional in a museum needs to be able to do, as well as the process through which a student might become a museum information professional, can be very unclear.

The root of this problem lies in the fact that there is no one traditional educational path which LIS students can follow that will lead them to a museum career. Despite the fact that museums are in desperate need of employees with the specific skills and abilities possessed by the graduates of LIS schools, exactly what one needs to do to become an information professional in a museum remains elusive. This paper, therefore, aims to provide guidance to students in LIS programs seeking careers in museums by presenting an analysis of the career paths, educational backgrounds, and on-the-job experiences of information professionals currently working in museums.

As part of a long-term exploration of the evolving importance of museum informatics, we have been studying the evolution of the museum information professional. In 2003, we conducted semi-structured interviews with twenty-one information professionals working in museums, asking them about their backgrounds and experiences with information resources, tools, and technologies in museums. From these interviews, we analyzed the criteria the museum community believe to be necessary for information professionals seeking museum careers. Based on this analysis, we developed five factors that we believe will influence the ability of information professionals to succeed in museum environments.

This article, therefore, will outline the career paths, educational backgrounds, and on-the-job experiences common to information professionals working in museums, and present five factors most likely to influence the ability of LIS students to pursue such careers. These results will help guide the careers of LIS students wishing to become museum information professionals, identifying the skills and abilities they need to acquire and providing guidance in choosing 
courses, programs of study, and internships. In doing so, it will answer the question, "How do I become an information professional in a museum?"

\section{Literature Review: The Museum Information Professional as a Career Choice}

In recent years, many professors of LIS have had the pleasure of helping students pursue careers as information professionals in museums. As museums worldwide increase their focus on the provision of information resources, in-house or online, the skills of the information professional increase in value and importance for the museum. Meeting the information management needs of museums today requires a joint effort on the part of museum professionals and information professionals from many different disciplines. Yet the question of how to become an information professional in a museum remains maddeningly difficult to answer, in part because we do not have a sufficient handle on what an information professional in a museum does.

\section{What does an information professional in a museum do?}

In some sense, of course, all museum professionals are information professionals. Museum professionals are well aware of the importance of providing access to information about museum objects, as well as the objects themselves. ${ }^{4}$ The past few decades in particular have seen a shift away from the idea that museums are mere repositories of objects to the notion that museums are repositories of knowledge. ${ }^{5}$ The museum is now seen as an information utility, and museum professionals have become as concerned with providing access to information about objects as access to the objects themselves. ${ }^{6}$ To be useful, however, the information resources contained in museums must be carefully maintained and managed, and it is now more important than ever for us to reconsider the role of information professionals in the museum. ${ }^{7}$

There are, naturally, many traditional museum careers, such as registrar or librarian, which require a great deal of experience and expertise working with information resources. ${ }^{8}$ Most would agree that individuals working in these positions are information professionals, and many of these individuals have degrees from LIS schools. When students in LIS programs begin exploring the possibilities of working in museums, it is no doubt these traditional careers which they first consider.

There is, however, a clear sense that a new role for the information professional is emerging in the museum. ${ }^{9}$ As museum administrators become increasingly concerned about the ability of their museums to function in the information society, many have begun looking for individuals capable of setting information policy, managing information resources, administering content management systems, implementing metadata standards, evaluating information interfaces, etc. While some of these tasks may be performed by existing employees, a growing number of museum administrators have begun seeking new individuals to fill new positions specifically designed to tackle these responsibilities.

Describing these new positions and their evolving responsibilities is challenging. Outside of small museums, it is rare that one individual would be responsible for performing all of these tasks. Depending on the size of the museum, these responsibilities might be met by several individuals or by an entire department. Those individuals might also possess many different 
titles, ranging from the very technical (webmaster, database designer, technical support specialist, etc.) to the more information-oriented (chief information officer, information resource manager, etc.). Despite these difficulties, several authors have attempted to define what a museum "information manager" might do.

"Perhaps there is a new role in museums for an 'information manager' who is charged with caring for the museum's information. [...] Few, if any, museums have a staff position with this title now, but the function will become increasingly important as we integrate information systems into our daily work."

"An information manager is a relatively new position for museums, but one of great importance for efficient operations and record-keeping. [...] The information manager is responsible for facilitating the flow of information within an institution and between the institution and the public. [...] Broadly interpreted, the activities include ongoing analysis and implementation of the ways in which the institution collects, stores, and disseminates information."

Additional perspectives on the nature of and the need for information professionals in museums can be found by analyzing job descriptions written by museum administrators seeking database managers, information architects, or similar positions. The following examples are taken from job descriptions posted on museum listservs and discussion boards over the past four years.

"Seeking an experience, energetic, and innovative manager who can lead the dynamic development of the museum's information infrastructure."12

"Responsible for design, development, and support of museum databases and database interfaces $[\ldots]$ and for defining the museum's strategic approach to information storage." 13

The broad coverage apparent in both definitions and job descriptions makes it clear that this position is one that can entail a variety of responsibilities and require a variety of skills. The role of the information professional in the museum is a continually evolving position that is still in the process of defining itself. ${ }^{14}$ The role is changing so rapidly that any attempt to define precisely the responsibilities associated with it likely would become quickly outdated, especially if one attempts to specify particular skills or technologies as requirements. In seeking individuals capable of filling such a position, then, museum administrators need employees who are just as capable of helping them define the very role they need to play in the museum. How can we prepare our students for such a changing and ill-defined position?

\section{How does one prepare for a career as an information professional in a museum?}

The difficulty with answering this question is that there is no one answer. We cannot say, if you follow steps $\mathrm{a}, \mathrm{b}$, and c, and learn topics $\mathrm{x}, \mathrm{y}$, and $\mathrm{z}$, you will be qualified for a career as a museum information professional. In part, this is because of the inherent difficulty of providing guidance for students who want museum careers in general: "Unlike many other professional fields of endeavor, there is no one training route into the museum field." ${ }^{\prime 5}$ Individuals seeking 
museum careers may need an advanced degree in an academic discipline, a museum studies degree, and years of experience working in museums. ${ }^{16}$

Individuals seeking careers as information professionals in museums face additional challenges because of the novelty of the position. With such a new and constantly evolving position, it is very difficult for museum administrators to specify even the skills that might be required. Without those details, students have a hard time preparing for a career as a museum information professional because they do not know what abilities they should acquire. The result is the unfortunate situation where potential employers want to hire museum information professionals, and potential employees want to become museum information professionals, but latter cannot prepare for positions that are not fixed, and former cannot offer positions for which there are few prospective employees. All the while, everyone from museum administrators to college students are trying to figure out what it actually means to be an information professional in a museum.

Despite these difficulties, the role of the museum information professional is one that will only grow in importance to museums in the future. To help LIS students prepare for this role, we need to learn more about the job of the museum information professional in the field today. We need more studies that explore what people working as information professionals in museums are actually doing, where they came from, how they got their jobs, and how they keep them. The best way to learn how to prepare our students for this career is to ask individuals currently working as museum information professionals about their own career paths, education backgrounds, and on-the-job experiences.

\section{Research Questions and Methods}

This study focused on addressing the following research question: How can LIS programs best prepare their students to pursue careers as museum information professionals? Answering this question required answered the following related questions about information professionals currently working in museums: What are the a) career paths; b) educational backgrounds; and c) on-the-job experiences of current museum information professionals?

This research is one part of a larger, exploratory study begun in order to understand the information skills, resources, and technologies that information professionals working in museums use on the job. It is also part of an ongoing research agenda in the area of museum informatics to determine how museum professionals are coping with rapid changes in the use of information technology and information resources in the museum environment. The results of this research should help guide the continuing professional development of current museum professionals as well as the education of information science or museum studies students considering future careers as museum information professionals.

To answer the above questions, we conducted 21 semi-structured interviews with information professionals working in museums, asking them about the information resources, tools and technologies they use daily on the job. Research participants were recruited from various national and international museum conferences where attendees are interested in the role of information professionals working in museums; given the lack of any existing registry for museum information professionals, it was determined that advertising this study at conferences 
likely to appeal to such individuals was the best way to locate and recruit potential participants. Although they varied widely in technical skills and expertise, all of the participants were responsible for managing information resources, tools, or technologies in a museum in some fashion.

Research participants worked at 17 different museums, including cultural heritage, science and technology, art, natural history and children's museums. They varied widely in technical skills and expertise and ranged from relatively lower-level positions to middle-managers to high-level administrators in their respective museums, having anywhere from one to 30 years worth of experience in the museum field. The participants came from diverse backgrounds and held a wide variety of jobs, including more traditional museum positions (such as curators, educators, or managers) as well as more modern, technology-oriented positions (such as webmasters, new media specialists, and chief information officers).

Participants were asked several questions during their interviews dealing directly with their career paths, educational background, and on-the-job experiences. These questions included:

- How long have you worked in the museum field? How long have you worked at your current position?

- What is your educational background? What was your career path?

- Do you feel you were adequately prepared for your current job, either in school or at a previous job?

- How do you compare the skills you learned on the job (past or present) with the skills you learned in school? What do you wish you had learned in school?

- For which skills/areas of your job are you most concerned about staying up to date? How do you stay current in these areas? Would you consider going back to school or taking continuing education courses to keep current?

Interviews each lasted approximately an hour, and were transcribed for qualitative data analysis and analyzed using grounded theory methodologies. Drawing upon the participants' answers to each of the above questions, we used a process of coding and memoing, as outlined by Strauss and Corbin, ${ }^{17}$ to develop an understanding of the process by which information professionals in museums obtained their current positions, as well as the relative value they attached to their career paths, educational backgrounds, and on-the-job experiences. This kind of analysis is an iterative, on-going process where participant responses are analyzed as part of a continual process of exploring the data to identify emergent themes and dimensions. By studying the past and present experiences of current museum information professionals, we were able to develop a better understanding of how one becomes an information professional in a museum, knowledge that can help current LIS students and educators in the future.

\section{Results: Analyzing the Careers of Information Professionals in Museums}

Studying how individuals pursue museum careers is a challenging exercise, particularly because most museum professionals have diverse career paths, different educational backgrounds, and a wide variety of on-the-job experiences. The twenty-one museum information professionals interviewed in this study were very different from each other in almost every respect: career 
ambitions and goals, courses pursued in college, years of museum experience, positions within the museum, levels of technical expertise, information literacy skills, etc. Despite these differences, there were several characteristics they shared that allow us to identify some general trends and concepts common to most museum information professionals (please note that, in the quotes that follow, we have included participant numbers for cross-referencing purposes, but removed all identifying information).

Overall, the participants did not expect to pursue careers as museum information professionals; more often than not, they found themselves stumbling accidentally into such careers. This came across clearly as they discussed their schooling, their previous jobs, and so on. Very few of the participants, for instance, selected college courses or pursued skills specifically because they were intentionally preparing for museum careers.

"I didn't say to myself, I want to learn $\mathrm{x}, \mathrm{y}$, and z skills because I want to work as a professional in a museum." [P04]

Given the accidental nature of their careers, the participants interviewed here could neither plan ahead for the positions they would eventually have, nor predict the skills or abilities that would be useful to them in advance. Many described how, when looking back over their careers, the experiences that proved most valuable were those that at the time seemed tangential or perhaps even unrelated to museum work.

"I kind of helped pay the bills through college doing desktop support for the college, and so we were exposed to the world wide web in its infancy and really kept up with that, kind of as a side project, something to keep us going between fixing computers to really see if we could catch onto something that was going to be pretty big. And I had no idea how big it was going to be when we started learning that stuff, and what was that, '93, but here it is, ten years later and it's changed the way that people do research, it's changed the way people communicate, and not just some people, but a large part of today's society has been changed in the way it seeks information and how that is delivered." [P07]

It is perhaps unsurprising, then, that the participants overwhelmingly emphasized the importance of having diverse backgrounds with a general body of knowledge. Given that the museum information professional faces constantly evolving job requirements and changing expectations from colleagues, administrators, and visitors in the museum, a general education with experience working in many different situations may be the best way to prepare for such a position.

"Having a general liberal arts background [...] makes people good generalists, so that they can deal with people in a wide variety of situations." [P06]

"[When hiring,] I always try to find people with really varied experiences [...] Often times people bring things from other careers or other fields that turn out to be very useful." [P01] 
Despite the different paths the participants took to their positions, each was dedicated to the belief that providing access to museum information resources was an important part of the job of the museum professional. They believed that a significant aspect of their jobs was to ensure that the information resources, tools, and technologies in use at the museum were available to the right people, in the right time, at the right place. Accomplishing this goal was deemed essential to the overall success of the museum.

"My job is to develop the use of technology in any way that helps the productivity, costeffectiveness of the institution in achieving its mission." [P19]

"I'm in charge of overseeing the technological spin on information in the museum, making sure that there is efficient access to that information, and that the staff's needs as to information technology are being met, and that they have the tools they need to access the databases, and other information sources and archives here at the museum." [P05]

With these points in mind, we will now present our research results, focusing on three main topics: career paths, educational background, and on-the-job experience.

\section{Career Paths}

The career paths followed by the research participants were so diverse that it would be impossible to describe each path in detail without violating the confidentiality of our participants. In general, however, the interviews indicated that there are two dimensions which play a major role in describing the typical career paths of museum information professionals: 1) the degree to which the individual has been involved with the museum community in the past; and 2) the intentionality of the individual's career as a museum information professional.

The degree to which the participants were involved with museum careers prior to becoming museum information professionals was an important factor in determining their ability to assimilate their skills as information professionals and museum professionals satisfactorily. Of the 21 research participants, 11 had prior museum experience while 10 had no prior museum experience. Those with prior museum experience generally followed a career path where, after several years of working in the museum field in a variety of positions, they assumed the role of a museum information professional. This change usually occurred when new needs and changing expectations within the museum necessitated the creation of a new position that coincided with the new skills and changing expertise of the museum professional.

"I was working in the marketing department here at the museum, and I had always been into computers, was doing stuff like that on the side, and [...] started to go to community college and taking web design courses and I really liked it. While that was going on, the museum had a webmaster, the museum first had a website in 1995, and they had been running it until about 1998, and they left and no one really took over the reins, [...] so they decided that got another line position and wanted to get someone for the website. So I was going to school, taking web design and working in the marketing department and I jumped at it as it came open and I got the job." [P12] 
Those individuals without prior museum experience generally followed a career path where, after several years working in non-museum, technology-oriented positions, they found work as an information professional in a museum. Frequently, these individuals came from more technology-oriented fields, finding museum jobs after an unexpected career change. For many, working in a museum gave them a chance to employ their technical skills while obtaining a certain amount of personal satisfaction at the same time.

"A couple years ago I was offered an early retirement [from a technical, non-museum position], so I took it and then of course the job market kind of went down the toilet here, so I looked around for something that I could do that would keep me technically involved, and there's some intrinsic payback of helping an organization, of course, so I found this job." [P11]

In almost every one of these cases, the participants were unable to plan their career moves very far in advance. As mentioned above, the vast majority of the research participants became information professionals working in museums only accidentally; only one of the 21 participants can be said to have intentionally pursued a career as a museum information professional. In this situation (generalized to protect the confidentiality of the participant), the individual is likely propelled by a lifelong interest in museums and information technology. To make herself more attractive to prospective employers, she seeks to acquire expertise in information management and advanced information technologies, focusing specifically on their use in the museum environment. Such individuals are rare, as they themselves usually recognize.

"I have a bachelor's degree with a double major in management of information systems and museum studies. [...] I saw the beginnings of computing in museums and in the humanities in general as an opportunity that I wanted to pursue. So I decided to add the museum studies aspect to my background and wanted to very specifically do pretty much exactly what I do. I think that I'm unusual in that regard." [P09]

Overall, the relative value of any one individual's career path is difficult to measure. Some clearly took very roundabout paths to get to where they are now, while others took slightly more straightforward, while still accidental, paths to their current positions. Some never intended to work in a museum at all, while others desired a career as a museum professional yet had not predicted the degree to which they would be involved with information resource management in the museum. While only one participant intentionally set out to become a museum information professional, all participants wound up playing important roles working with information resources, tools, and technologies in museums.

Today, against this backdrop of diverse and overwhelmingly accidental careers, a number of LIS students are intentionally deciding to pursue careers as information professionals in museums. What guidance can we give these students in terms of the education they should pursue? We can answer this question by examining what current information professionals in museums have to say about the relative values of their own educational backgrounds.

\section{Educational Background}


As with their career paths, the educational backgrounds of the research participants varied tremendously, and we cannot describe each individual's background in detail without violating the confidentiality of our participants. In general, however, our interviews indicated that there are three dimensions that play a major role in defining the typical education backgrounds of museum information professionals: 1) the individual's background in a subject domain or discipline appropriate to the museum's collections; 2) the individual's background in museum studies; 3 ) the individual's background in information science and technology.

Domain or discipline-based training has always been an important part of the education of museum professionals. ${ }^{18}$ Historically, it was more or less assumed that a background in art history was required to work in an art museum, anthropology for a world cultures museum, history for a history museum, and so on. While completing a degree in one of these fields may have little to do with whether an individual decides to pursue a museum career, those without this domain or discipline-based knowledge may find it difficult to operate as a museum community insider after landing a museum job. While this may certainly be true for a museum curator, for instance, the question arises: is such a background necessary for the information professional seeking a museum career?

Of the 21 research participants, 9 of them had a specific educational background in a domain or discipline related to the museum where they worked. In general, those individuals felt that this background was beneficial, no matter how their jobs changed over time, specifically because it helped them better understand the role of the museum in general. Frequently, the participants wished that they had studied or acquired even more knowledge in a particular domain.

"I wish I knew a lot more about art history, I wish I had taken lots more classes and hung out with the art history students a lot more. I mean art history is so big, the art world is so big, and you cannot know everything. I find that I'm already slipping in my specialty, it's hard to keep current in your own very narrow, very needle, you know, part of the pin, it's hard to keep current in. I just wish I knew everything." [P15]

There is also the belief, however, that the relative value of a domain or discipline-based educational background decreases as museum jobs become more fragmented. This goes hand in hand with the growing school of thought that for certain, more specialized positions, it is more important for the future museum professional to have an educational background in business, communications, design, etc. This is especially the case in large museums, where it may be far more important that the museum director have an MBA and prior experience as a CEO, than a Ph.D. in art history and prior experience in academia. The 11 participants interviewed whose educational backgrounds were in disciplines unrelated to the subject matter of the museum where they worked certainly felt that they brought valuable skills with them to the museum.

"I come with certain business skills and knowledge of educational facilities, knowledge of government facilities, public facilities, knowledge of technology, and how can we do things better using technology, and that is my driving objective, is to be able to do something better using technology, to support what is the end mission and objective of all of the departments, regardless of what area they may be focusing on, what can we do to 
integrate technology in what the mission and the objectives are in all of those areas." [P18]

The importance of having an educational background in a particular domain or discipline is related to the changing value of museum studies as an academic field. In the past, a degree in museum studies was considered less valuable than a degree in, say, art history as preparation for a museum career. This is no longer the case: "Skepticism about museum studies programs as one route into the museum field was once the norm, but now has virtually disappeared.",19 Nevertheless, only three of our 21 participants had an educational background in museum studies. Although each desired a degree in museum studies specifically because they intended to pursue museum career, each also pursued museum studies primarily to complement their ongoing education in a more traditional, discipline-based field. Despite this, the attitude of our participants towards museum studies programs was generally favorable, with most agreeing that their museum studies preparations were helpful.

"I think my work [in museum studies] did certainly inform what I was doing at the [museum] and the way I worked subsequently" [P14]

One might expect that the increasing significance of museum informatics for museums would make degrees from information science and technology-oriented degrees (LIS, CS, MIS, etc.) appealing to those individuals interested in pursuing museum careers. Of our 21 participants, however, only one actively pursued a degree in an information technology-type program in order to prepare for a job as an information professional in a museum. While five others had backgrounds in information technology (primarily computer science), none of them had experience working in museums prior to beginning their current positions. Most participants with strengths in information technology were aware that their skills were valuable to museums; even participants without formal degrees from information technology programs considered the acquisition of knowledge about information technology to be useful.

"I did a pretty intensive hands-on internship to develop websites. It was about three months of learning how to code websites, learning how to use an editor, learning Photoshop, learning about image resolution, image management, manipulation; it was through that kind of internship that I actually learned a lot of skills that got me my job at the museum." [P08]

On the other hand, however, a number of participants stressed the importance of developing skills with the "information" side and not just the "technology" side of information technology. While having technological skills was certainly important, being able to apply those skills within the context of the museum as an information organization was far more important. In addition, certain participants emphasized the importance of "information science" skills, arguing that they were not only more important, but also more difficult to acquire, than "information technology" skills.

"I knew how to handle information. Forget about the technology. Anybody can learn the technology. It's a lot more difficult to learn information.” [P19] 
The need to apply information technology skills within the context of the museum is indicative of the importance of developing skills in all three areas: a subject domain or discipline, museum studies, and information science and technology. The participants who came from mixed, or hybrid, backgrounds frequently emphasized the value obtained from combining different educational backgrounds while working as a museum information professional. They especially valued their abilities to contribute across boundaries within the museum.

'It was a combination of having a master's in art history, so knowing the formal art history background, and specifically 20th century art, and we are a modern, contemporary art museum. Having the corporate website experience, bringing those two things together, I think really has helped me feel prepared for the job. The academic background in the content area of art history and the real world technical experience, working on some corporate websites, in private sector settings, really helps, I think. A unique combination giving me this background helps a lot, you know, in my current position. It gives me more credibility; I'm not just the technical person who doesn't know anything about the subject matter." [P10]

This quote also nicely emphasizes the importance of having "credibility" while working as an information professional in a museum. While having an appropriate educational background is one way of gaining this credibility, most participants did not consider it the best approach. As in almost any field, the best ways of gaining credibility within the museum is through on-the-job experience working in museums.

"It was more experience that prepared me for [my job] rather than formal education." [P14]

\section{On-the-Job Experience}

All 21 participants emphasized the importance of on-the-job experience in the continuing education and training of museum information professionals. It is likely that this was because of their extremely diverse educational backgrounds and career paths; on-the-job experience was the best way to gain the shared perspectives of museum community insiders. According to our interviews, there were three dimensions that best described the ways our participants obtained on-the-job experience: 1) experiential or project-based learning; 2) formal training sessions or continuing education courses; and 3) miscellaneous, informal methods of keeping current.

One of the best ways to gain on-the-job experience, according to all 21 participants, was through experiential or project-based learning. The museum information professionals we interviewed were frequently asked to complete unfamiliar projects requiring the acquisition of new skills. Given the importance of on-the-job learning for augmenting the skills learned in school, it was especially valuable for participants to be involved in such activities. For most participants, this was the single most valuable way for them to push old boundaries and test new responsibilities.

"I think that it's really the experience that comes along in working on projects that kind of has the side of the unknown to them is vital for gaining the skills that complete these things, for gaining the familiarity with the resources available." [P07] 
Experiential learning was generally considered to be more useful than formal training sessions or continuing education courses, although some participants admitted to finding such methods of gaining on-the-job experience to be valuable. While only a few (3 of 21) said they would be interested in going back to school to learn more skills, nearly half (10 of 21) stated they had taken or planned to take some type of continuing education. Participants were especially interested in courses, workshops, or seminars that could be offered either locally or at professional conferences by museum professionals or other experts.

"It would actually be helpful for someone in my position to keep taking continuing education courses, just to take some courses in areas where I've had on the job experience but have not had the formal training, just to make sure I didn't do something wrong." [P06]

"I think the education process is an ongoing process, and so just get out there and attend the seminars, attend the presentations as well as formal training, so you know everything that's out there." [P18]

Finally, given the need for museum information professionals to constantly learn new skills and acquire new abilities, all 21 of the participants interviewed stressed the importance of keeping current in their particular specialties. Although some were more actively involved in this process than others, no one wanted to "fall behind," and the participants employed a variety of methods for maintaining their expertise. Informal methods of keeping current included reading mailing lists, subscribing to academic journals, participating in online discussion forums, and collaborating with colleagues on joint projects.

"I subscribe to various journals and I have quite a few e-bulletins, you know newsletters, I get emails updating me on [various] issues, so I have a lot of electronic things coming in. I look at the internet, different websites, to find out what's happening, certainly. I talk to colleagues in other institutions about what they're doing." [P14]

"I try to read every single journal that comes across my desk before I haul it up to the library and put it on the periodicals rack. If it has any relevance whatsoever to anything I'm working on or may work on in the future, I try to read each article. Sometimes I discover that 'gee, I think I saw something five months ago on this', and so I at least know that I've seen it somewhere and I can try to recapture it. but keeping current is really, really hard and there are probably lots of ways you can do that, the easiest and most efficient way for me, the one that takes the least amount of effort on my part, is just reading the journals." [P15]

\section{Discussion: The Keys to a Career as a Museum Information Professional}

Given the wide variations in career paths, educational backgrounds, and on-the-job experiences discussed above, one may well ask: how can we prepare our students for the constantly evolving, difficult to define, hard to acquire career as an information professional in a museum? Based on our analysis, we have developed five factors that will play an important role in the LIS student's 
ability to become an information professional in a museum. For the near future at least, we believe that these factors are the keys to a career as a museum information professional.

Factor 1: The museum information professional will benefit by having expertise or credentials in a background domain or discipline relevant to the museum where he or she works.

Although the relative value of such a background is decreasing as museum jobs become more specialized, it is still important that students pursuing museum careers be able to understand the context in which they will work. When solving information management problems, it certainly helps if one understands the nature of the museum's collection and knows how to talk with other employees about the artifacts the museum acquires. Even those students seeking extremely technical positions, webmaster or database designer, for instance, will benefit from having some experience with or knowledge of the museum's specific domain or discipline.

"To put that content on the web, you're supposed to understand it, and understand the difference between one artist and another, and what's appropriate, you know, what's the appropriate treatment of one artist's artwork on the web versus another artist or artist's work. You can't look at it in isolation, you have to understand the subject matter and not just be, 'oh, we're going to put stuff on the website' without thinking about what it is we're putting up. And so therefore understanding that content is immensely helpful." [P10]

Factor 2: The museum information professional will benefit by having expertise or credentials in Library and Information Science relevant to the museum where he or she works.

Clearly, the information professional who wants to work in a museum needs credentials in LIS (or a related field). It is equally important, however, that the future museum employee be able to explain why his or her skills in LIS will prove valuable to the museum in the long run. This is likely harder than it sounds, as the evolving nature of museum informatics projects leaves the relative importance of different LIS skills open to interpretation. LIS faculty will need to keep track of museum projects that rely on LIS skills, in order to help LIS students select courses that will allow them to gain expertise in related areas.

"[If I were in school today,] I would expect to be learning a lot about metadata and layers of description and I would expect to be learning about imaging and html and all of these tools that people need to know how to be able to know how to use in order to be effective in delivering information. In addition to the theories and cataloging standards and schools of thought about describing things, I think all those more theoretical aspects would be critical. I also think that library and information science schools, if they're going to try to address museum needs, need to also be talking about the tools that you have to know how to use to deliver information." [P09]

Factor 3: The museum information professional will benefit by having expertise or credentials in Museum Studies relevant to the museum where he or she works. 
While the inherent value of a museum studies degree varies from museum to museum, the ability to understand and cogently discuss museum studies as an academic discipline in its own right is extremely valuable. Even if LIS students are unable to pursue a full degree program in museum studies, just taking a few courses or perhaps gaining a certificate in museum studies will help them gain an understanding of what it means to work in a museum. While perhaps not essential for all students seeking positions as museum information professionals, a strong familiarity with the museum culture can only help those students keep their jobs in the long run.

"I was able to take courses in curatorship and collections management and legal issues in museums and courses like that, that basically familiarized me with what happens in a museum and what kinds of information management needs museums have." [P09]

"You cannot work in a museum unless you understand the museum culture." [P20]

Factor 4: The museum information professional will benefit by having prior experience working in a museum.

Along with the importance of understanding the museum culture, it is essential that LIS students seeking museum careers acquire some prior experience working in museums. It is not always necessary that this experience be in a paying position; even volunteer activities or internships can help students demonstrate that they are familiar with the museum approach to information management and understand the museum's unique information needs.

"What helps me is just working with the people here on a day to day basis for the past several years and learning how they do their jobs and what sort of tasks are going on." [P05]

No matter how skilled any one information professional might be, fitting into the museum culture can be difficult. Without having prior museum experience, information professionals risk feeling like an outsider while working in museums.

"I still feel like a computer scientist working in a museum. [...] I do feel like I've learned a lot about the museum environment, definitely, and I understand, you know, some of the fundraising and some of those types of things now that I didn't know before, but I still think of myself that way, as a computer scientist in a museum." [P11]

Factor 5: The museum information professional will benefit by having the ability to learn new skills and face new challenges on the job.

As museums come to rely more and more on the skills of the information professional, their needs and requirements will continue to change, becoming both more elaborate and more complex. The successful museum information professional will be one that has the ability to grow with these changes, learning new skills that will allow him or her to face new challenges successfully. Doing this well requires not just the ability to learn on the job, but also the attitude that one's job is never static, and that only by pushing new boundaries can we improve the way museums manage information resources, tools, and technologies. 
"Preparing myself for future technologies is always my concern in the broader sense, because technologies change so quickly." [P11]

"You know, I can view today's work, and as I said earlier, the me of five years ago could not do today's job, and so I've kind of always got one eye out for what's the next new thing, or what's a better way to do whatever I'm doing. I'm always pushing myself in kind of taking what I'm in a habit of doing and creep it forward, but also keeping an eye on the future picture." [P07]

\section{Conclusion}

This paper presented an overview of the career paths, educational backgrounds, and on-the-job experiences shared by 21 information professionals working in museums. Based on a qualitative analysis of these data, we identified five factors influential in the LIS student's ability to pursue a career as a museum information professional. As the number of students interested in such careers continues to increase, these factors should help them plan courses of study, gain valuable skills, and gather necessary experiences as they prepare for a future in museums.

There are two main limitations to this study. First, the five factors identified above are rather obvious. We are arguing, after all, that students will find it helpful to have expertise in a museum-related discipline, plus museum studies, plus LIS and/or IT, not to mention several years worth of experience working in museums as well as the intelligence necessary to keep their jobs as their job requirements change over time. While this may be obvious in retrospect, it is always helpful, we believe, to have the obvious readily available, and one should note that prior to this study, no one had formally codified the career paths, educational backgrounds, and onthe-job experiences that would help the museum information professional.

The second limitation, perhaps, is more serious. It is literally ridiculous to expect that any one student will actually go to the effort to fulfill all five of these factors just to work in a museum. Doing this correctly could very well entail that student pursuing multiple bachelor's degrees, multiple master's degrees, possibly even a Ph.D., not to mention as many IT certification programs as the student can afford, plus years of museum experience (which most likely will be unpaid or poorly paid positions), all so that the student can land a job that will pay, if the student is lucky, around $\$ 35,000$ a year. This, obviously, is not going to happen.

If we are truly serious about encouraging our students to pursue careers as museum information professionals, then we need to find ways of streamlining the process, so that our students can fulfill the spirit of these five factors reasonably. This will mean enhancing existing programs so that they encourage students to gain discipline-based expertise in museum-related areas while working on their LIS degrees, assist students in gaining experience through internships with local museums where they can apply their LIS skills, and offer courses that help students learn more about the role of information professionals in museums, past, present, and future.

Making these changes may not be easy: too few LIS programs are located in universities that also have museum studies programs; too few have courses focusing on the unique information 
needs of museums; and too few have the collaborative relationships with museums necessary to provide suitable internships and experience-building projects for their students.

Nevertheless, if LIS faculty are truly serious about encouraging their students to pursue museum careers, it is crucial that they find ways of giving their students the skills they need to survive in the museum environment. If LIS students are serious about working in museums as information professionals, then they must seriously consider fulfilling, to the best of their abilities, the five factors identified above. And if we are serious about guiding the careers of museum information professionals in ways that will be helpful, we need to find methods of achieving these goals quickly, easily, and as cheaply as possible.

This will undoubtedly require a joint effort, where LIS programs, museum studies programs, and museums of all types collaborate to identify the best approaches for sharing personnel, courses, resources, and expertise in order to guide students from multiple backgrounds, through multiple programs, to one shared conclusion. If we are to meet head on the challenges of museum informatics, information professionals, museum professionals, and faculty and students from LIS and museum studies programs will need to work together, drawing from their diverse backgrounds the skills and experiences necessary to solve common problems. Only in this way will our students be able to demonstrate that they possess those characteristics that will convince a museum administrator to take a chance on a budding information professional.

\section{Acknowledgements}

The author would like to acknowledge the hard work and dedication of the museum professionals who participated in this research. Without their contributions, this project would never have been possible. The author would also like to acknowledge the efforts of his research assistant, Anna Wilcoxon, who is a master's student in the College of Information.

\section{References and Notes}

\footnotetext{
${ }^{1}$ Paul F. Marty, "The Evolving Roles of Information Professionals in Museums," Bulletin of the American Society for Information Science and Technology 30 no. 5 (2004): 20-23.

${ }^{2}$ Paul F. Marty, W. Boyd Rayward, and Michael B. Twidale, "Museum Informatics," Annual Review of Information Science and Technology 37 (2003): 259-294.

${ }^{3}$ Guy Hermann, "Shortcuts to Oz: Strategies and Tactics for Getting Museums to the Emerald City," in The Wired Museum: Emerging Technology and Changing Paradigms, ed. Katherine Jones-Garmil (Washington, D.C.: American Association of Museums, 1997), 65-91.

${ }^{4}$ Wilcomb E. Washburn, “Collecting Information, Not Objects,” Museum News 62 (1984): 5-15.

${ }^{5}$ Peter Cannon-Brookes, "The Nature of Museum Collections," in Manual of Curatorship, ed. JMA Thompson (London: Butterworth, 1992), 500-512; Eilean Hooper-Greenhill, Museums and the Shaping of Knowledge (London: Routledge, 1992).
} 
${ }^{6}$ Elizabeth Orna and Charles Pettitt, Information Management in Museums (Aldershot: Gower, 1998); George F. MacDonald, “The Museum as Information Utility," Museum Management and Curatorship 10 (1991): 305-311; Patricia Ann Reed and Jane Sledge, "Thinking about Museum Information," Library Trends 37 no. 2 (1988): 220-231.

${ }^{7}$ W. Boyd Rayward, "Electronic Information and the Functional Integration of Libraries, Museums and Archives," in History and Electronic Artifacts, ed. E. Higgs (Oxford: Oxford University Press, 1998), 207-224; Layna White, "Museum Informatics: Collections, People, Access, and Use," Bulletin of the American Society for Information Science and Technology 30 no. 5 (2004): 9-10; cf. Anne Gilliland-Swetland and Layna White, "Museum Information Professionals as Providers and Users of Online Resources," Bulletin of the American Society for Information Science and Technology 30 no. 5 (2004): 23-27.

${ }^{8}$ Victor J. Danilov, Museum Careers and Training: A Professional Guide, (Westport, CT: Greenwood Press, 1994); Jane R. Glaser and Artemis A. Zenetou, Museums: A Place to Work. Planning Museum Careers (London: Routledge, 1996); American Association of Museums, Careers in Museums: A Variety of Vocations (Washington, DC: American Association of Museums, 1994).

${ }^{9}$ Ken Hamma, "Becoming Digital” Bulletin of the American Society for Information Science and Technology 30 no. 5 (2004): 11-13; Alice Grant, "Cataloguing is Dead: Long Live the Cataloguers!' The Changing Role of Museum Information Professionals in Mediating Museum Knowledge," mda Information 5 no. 3 (2001): 19-22; Geert-Jan Koot, "Museum Librarians as Information Strategists," INSPEL 35 no. 4 (2001): 248-258; Andrew Roberts, “The Changing Role of Information Professionals in Museums," mda Information 5 no. 3 (2001).

${ }^{10}$ Hermann, "Shortcuts to Oz," 75.

${ }^{11}$ Glaser and Zenetou, Museums: A Place to Work, 103.

${ }^{12}$ Position announcement from the Natural History Museum (London) posted on December 14, 2001, to the Cultivate-List listserv, http://lists.ukoln.ac.uk/cultivate-list/0234.html

${ }^{13}$ Position announcement from the Field Museum (Chicago) posted on March 18, 2002, to the Field Museum website, http://www.fieldmuseum.org/

${ }^{14}$ Marty, "The Evolving Roles of Information Professionals in Museums."

${ }^{15}$ Glaser and Zenetou, Museums: A Place to Work, 158.

${ }^{16}$ G. Ellis Burkaw, Introduction to Museum Work (Walnut Creek, CA: AltaMira Press, 1997); Marjorie Schwarzer, Graduate Training in Museum Studies: What Students Need to Know (Washington D.C.: American Association of Museums, 2001). 
${ }^{17}$ Anselm Strauss and Juliet Corbin, Basics of Qualitative Research (Thousand Oaks, CA: Sage, 1998).

${ }^{18}$ Cf. Glaser and Zenetou, Museums: A Place to Work.

${ }^{19}$ Glaser and Zenetou, Museums: A Place to Work, 159. 